\title{
Mutagenic studies on the effect of Aldicarb "Temik" and vitamin C as antioxidant agent on the white rat: (Chromosomal aberrations and Micronucleus tests)
}

\author{
Fatma M. Hamam* and Ihab H. Foda \\ *Department Of Mammalian Toxicology, Central Agricultural Pesticides Laboratory, \\ Agricultural Research Center, Ministry Of Agriculture.
}

\begin{abstract}
Widespread contamination of the environment due to increased and frequently indiscriminate usage of insecticides during the last two decades has aroused much concern over the possibility of their radiominetic effect. Evidence accumulating over the years emphasized the indisputable link between certain insecticides, chromosomal damage and possibility of gene mutation. There is a wide variety of insecticides, among which the carbamates. Their chemical relationship to ethyl carbamate makes them worthy of study for their possible deleterious effect on biological system. The main object of the present study is to evaluate the mutagenic effect of a carbamate insecticide" Aldicarb" alone and in combination of vitamin C as an antioxidant agent to decrease their mutagenicity. Male albino rats were tested orally for 48 hours, two doses of aldicarb were used in absence and in the presence of viamin C (1/4 and 1/10) LD50. The obtained data showed highly significant increase in the micronucleus (PCEM) and in chromosomal aberrations in rat bone marrow cells at the two doses of aldicarb compared to control group. $(\mathrm{P}<0.0001)$. The frequency of chromosomal aberrations and micronucleus decreased in rats treated with aldicarb and vitamin $\mathrm{C}$ than in aldicarb treated group. From these results we concluded that cytogenetic effect of aldicarb might be decreased by the usage of vitamin as an antioxidant agent.
\end{abstract}

Key words : Carbamate, Aldicarb, Chromosomal aberration, Micronucleus, Antioxidant agents.

\section{Introduction}

The genetic integrity of human populations is increasingly under threat due to industrial activities, which result in exposure to chemical and physical genotoxins. Other factors, which can influence genetic damage, include life style factors. E.g. diet, various medical therapies, and climatic damage e.g., increased exposure to UV radiation due to depletion of atmospheric ozone (Fenech, 1993). According to IARC (1991) more than 25\% of pesticides are classified as oncogens. Changes in genetic material are the basis of this process because many environmental pollutants are chemical carcinogens and mutagen with the capacity of causing DNA damage (ElKhatib and Rokaya, 2001).

The testing for genetic damage induction has been carried out by different approaches, although in human biomonitoring studies, the cytogenetic assays are the most commonly used (Pastor et al., 2001). Chromosomal aberrations (CA) may be used as an early warning signal for cancer development, and it has been suggested that the detection of an increase in chromosomal aberration, related to an exposure to genotoxic agents, may be used to estimate cancer risk (Carrano and Natarajan, 1988 and Hagmar et al., 1994). The observation that chromosomal damage can be caused by exposure to ionizing radiation or carcinogenic chemicals was among the first reliable evidence that physical and chemical agents can cause major alternations to the genetic material of euokaryotic cells (Evans, 1977). In the classical cytogenetic technique 
chromosomal aberrations are studied directly by observing and counting aberrations in metaphases (Natarjan and Obe, 1982). Heddle (1973) and Schmid (1975) noticed an alternative and simpler approach to assess chromosomal damage in vivo by measuring micronuclei (MNI), in dividing cell populations such as the bone marrow. The sensitivity and reliability of the micronucleus (MN) assay to detect DNA damage, makes it a good method to analyze the potential cytogenetic damage of environmental pollutants (Surralles et al., 1992; Kirsch- Volders et al., 1997 and Przygoda et al., 1999). Thus, many studies have demonstrated the efficiency of the micronucleus assay to detect DNA damage induced by pesticides (Comez-Arroyo et al., 2000 and da-Silvo et al., 1997).

Aldicarb 2 methyle-2- (methylthio) proprionaldehyde-omethylcarbamoyloxime, is an oxime carbamate insecticide sold under the trade name temik. The primary mechanism of toxic action is cholinesterase inhibition through a reversible carbamylation of acetyl-cholinestrase (Risher et al., 1987). It has on oral LD50 in the rate of 2 $\mathrm{mg} / \mathrm{kg}$. Aldicarb (temik) is a commonly used, very potent carbamate pesticide that has appeared at toxic levels in certain foods (Goldman et al., 1990; Goldman, 1995). While its toxicity and exposure hazards have been widely studied (reviewed in Baron, 1994; Risher et al., 1987). Pilot studies in our laboratory showed it to be moderately more toxic in young rats. Thus, we used in the present study two cytogenetic endpoints chromosomal aberrations and micronucleus tests ( $\mathrm{CA}$ and $\mathrm{MN}$ ) to assess if the subacute exposure to aldicarb alone causes genetic damage and the role of vitamin $\mathrm{C}$ as antioxidant agent to minimize its mutagenicity.

\section{Materials And Methods}

The commercial grade of aldicarb was used in the present study. It was were kindly supplied by the Central Agriculture Pesticides Laboratory (CAPL), also all the cytogenetic laboratory experiments have been operated at the mammalian toxicology department, CAPL, Dokki, Giza, Egypt.

\section{Experimental animals:}

Young Mature male albino rats were used in the present study. Rats, weighing 100-120 g; were obtained from the "Egyptian Organization for Biological Products and Vaccines". Animals were caged in 6 groups (5 animals for each group). We employed oral administration by stomach tube as route of exposure in this study. The rats from the six different groups used in this work were injected with a single dose for 48 hours, G1 ( $1 / 4$ LD50), G2 $(1 / 10$ LD50), G3 $(1 / 4$ LD50+Vitamin c), G4 $(1 / 10$ LD50 + Vitamin c), G5 (Control of Vitamin C) and G6 (Negative control).

\section{Experimental procedure:}

-For chromosomal aberrations: Colchicine $(4 \mathrm{mg} / \mathrm{kg}$ b.wt) was administrated intraperitoneally $2 \mathrm{~h}$ prior to sacrifice of animals in order to arrest mitosis. Rats were sacrificed by cervical dislocation. Bone marrow of both femurs was removed by flushing with $0.075 \mathrm{M}$ potassium chloride and incubated at $37{ }^{\circ} \mathrm{C}$ for $30 \mathrm{~min}$. It was centrifuged and fixed in cold methanol/glacial acetic acid 3:1 and processed according to the standard method of Preston et al. (1987). After 2h fixation, the cells were centrifuged and resuspended in the same fixative for $24 \mathrm{~h}$. The fixed cells were dropped on chilled slides from a height of about 2-2.5 m. The slides were dried, stained with $10 \%$ Giemsa stain. 30-50\% metaphase plates from each of the animals per dose were scored.

-For Micronucleus test: The procedure described by Schmid (1975), with some modifications recommended by Alder (1984), was followed. Bone marrow cells were flushed out with $2 \mathrm{ml}$ of fetal calf serum (FCS) and pipette several times. The cell suspension was centrifuged and the cell pellet was resuspended in a small amount of FCS and smeared on clean glass slide. The slides were fixed in methanol for $20 \mathrm{~min}$ and stained with wright followed by Giemsa stain. The frequency of micronucleated cells was scored in each 500-1000 polychromatic erythrocytes (PCE). 


\section{Statistical analysis:}

The obtained data were calculated and statistically analyzed using T-test

(Sendecore, 1969).

\section{Results}

The chromosomal aberrations in rats bone marrow cells exposed to aldicarb in the six different treated groups from (G1G6) were shown in table ( 1 ).

A highly significant increase in the induction of chromosomal aberrations was found in bone marrow of rats treated with aldicarb alone $(1 / 4$ and $1 / 10$ LD50) when compared to negative control $(\mathrm{P}<0.0001)$. The percentage of total number of aberrant cells was $45.5 \%$ and $35 \%$ in $1 / 4$ and $1 / 10$ LD50 doses of aldicarb respectively.

In addition animal groups exposed to vitamin $\mathrm{C}$ with aldicarb showed an increase in the frequency of chromosomal aberrations with significance $\mathrm{P}<0.0001$ when compared to vitamin control and negative control. The percentage of of total number of aberrant cells was $32.5 \%$ and $25 \%$ in $1 / 4$ and $1 / 10$ LD50 of aldicarb and vitamin C respectively.

While the incidence of CA decreased in the group treated with vitamin $\mathrm{C}$ and aldicarb compared with aldicarb alone. The most frequent type of aberrations is gap with the percentage of $16,13,9,7,2.5$ and $2 \%$ in six groups of treatment respectively, followed by break with the percentage of $5.5,5,4,5.5,0.5,1 \%$; deletion $4,3,4.5,2$, $0.5,0.5 \%$; fragment $2,1,0,0,0.5,1 \%$; d$\min 1,1,1.5,0.5,0,0 \%$ and dicentric $1,0.5,1.5,1,0,0, \%$. While the percentage of total number of numerical aberrations was $13.5,10,9,7,0,0.5 \%$ from G1 to G6 groups respectively.

The different types of chromosomal structural and numerical aberrations observed in different treatments groups were shown in fig (1).

On the other hand, table (2) summarized the obtained mean of the induction of micronuclei in polychromatic erythrocytes (PCEM) in rat bone marrow cells of the six different treated groups. The data showed that using of aldicarb alone with the two different doses increased the frequency of total number of PCEM when compared to the remaining four groups of treatments The percentage of PCEM cells was $6.8 \%, 5.6 \%, 4.2 \%, 2.9 \%$, $0.75 \%$ and $0.325 \%$ from G1 to G6 respectively. The statistical analysis also revealed that there was a high increase in the induction of $\mathrm{MN}$ in bone marrow cells of rats treated with aldicarb alone in two doses used (G1, G2) which decreased gradually from (G3, G4) due to the presence of vitamin $\mathrm{C}$ until reach the normal level in control groups (G5, G6).

The micronuclei in PCEM in bone marrow of rats were shown in fig (2). 
Table (1) Chromosomal aberrations in bone marrow cells of rats in the different treated groups.

\begin{tabular}{|c|c|c|c|c|c|c|c|c|c|c|c|c|c|}
\hline \multirow{2}{*}{\multicolumn{2}{|c|}{ Treatment }} & \multirow{3}{*}{$\begin{array}{c}\text { Total } \\
\text { No. } \\
\text { Of } \\
\text { exam } \\
\text { ined } \\
\text { cells } \\
200\end{array}$} & \multirow{3}{*}{$\begin{array}{c}\text { Total } \\
\text { No. } \\
\text { Of } \\
\text { norm } \\
\text { al } \\
\text { cells } \\
109 \\
\end{array}$} & \multirow{3}{*}{$\begin{array}{c}\text { Total } \\
\text { No. } \\
\text { Of } \\
\text { aberr } \\
\text { ant } \\
\text { cells } \\
91^{\star \star \star} \\
\end{array}$} & \multicolumn{8}{|c|}{ Structural aberrations } & \multirow{3}{*}{$\begin{array}{c}\text { Numerical } \\
\text { aberra., } \\
\text { Polyploidy }\end{array}$} \\
\hline & & & & & \multirow{2}{*}{$\begin{array}{c}\text { Gap } \\
32 \\
\end{array}$} & \multirow{2}{*}{$\begin{array}{c}\text { Break } \\
11 \\
\end{array}$} & \multirow{2}{*}{$\begin{array}{c}\text { Deleti } \\
\text { on }\end{array}$} & \multirow{2}{*}{$\begin{array}{c}\text { Frag } \\
4 \\
\end{array}$} & \multirow{2}{*}{$\begin{array}{c}\begin{array}{c}\text { Acent } \\
\text { ric } \\
\text { Frag }\end{array} \\
4 \\
\end{array}$} & \multirow{2}{*}{$\begin{array}{c}\text { D- } \\
\text { min } \\
2 \\
\end{array}$} & \multirow{2}{*}{$\begin{array}{c}\text { Ring } \\
1 \\
\end{array}$} & \multirow{2}{*}{$\begin{array}{c}\begin{array}{c}\text { Dicen } \\
\text { tric }\end{array} \\
2\end{array}$} & \\
\hline & No & & & & & & & & & & & & \\
\hline Aldicarb & $\%$ & 100 & 54.5 & 45.5 & 16 & 5.5 & 4 & 2 & 2 & 1 & 0.5 & 1 & 13.5 \\
\hline \multirow{2}{*}{$\begin{array}{c}\mathrm{G}_{2} \\
1 / 10 \mathrm{LD} 50 \\
\text { of } \\
\text { Aldicarb } \\
\end{array}$} & No & 200 & 130 & $70^{\star \star * *}$ & 26 & 10 & 6 & 2 & 3 & 2 & 0 & 1 & 20 \\
\hline & $\%$ & 100 & 65 & 35 & 13 & 5 & 3 & 1.5 & 1.5 & 1 & 0 & 0.5 & 10 \\
\hline \multirow{2}{*}{$\begin{array}{c}\mathrm{G}_{3} \\
1 / 4 \mathrm{LD} 50 \\
\text { Aldicarb+ } \\
\text { vitamin C } \\
\end{array}$} & No & 200 & 135 & $65^{\star \star \star}$ & 18 & 8 & 9 & 0 & 3 & 3 & 3 & 3 & 18 \\
\hline & $\%$ & 100 & 67.5 & 32.5 & 9 & 4 & 4.5 & 0 & 1.5 & 1.5 & 1.5 & 1.5 & 9 \\
\hline \multirow{2}{*}{$\begin{array}{c}\mathbf{G}_{4} \\
1 / 10 \text { LD50 } \\
\text { Aldicarb } \\
\text { + vitamin } \\
\text { C } \\
\end{array}$} & No & 200 & 150 & $50^{\star \star \star}$ & 14 & 11 & 4 & 0 & 1 & 1 & 3 & 2 & 14 \\
\hline & $\%$ & 100 & 75 & 25 & 7 & 5.5 & 2 & 0 & 0.5 & 0.5 & 1.5 & 1 & 7 \\
\hline \multirow{2}{*}{$\begin{array}{c}\mathrm{G}_{5} \\
\text { Control of } \\
\text { vitamin } \mathrm{C}\end{array}$} & No & 200 & 192 & 8 & 5 & 1 & 1 & 1 & 0 & 0 & 0 & 0 & 0 \\
\hline & $\%$ & 100 & 96 & 4 & 2.5 & 0.5 & 0.5 & 0.5 & 0 & 0 & 0 & 0 & 0 \\
\hline \multirow{2}{*}{$\begin{array}{c}\mathrm{G}_{6} \\
\text { Negative } \\
\text { Control } \\
\end{array}$} & No & 200 & 190 & 10 & 4 & 2 & 1 & 2 & 0 & 0 & 0 & 0 & 1 \\
\hline & $\%$ & 100 & 95 & 5 & 2 & 1 & 0.5 & 1 & 0 & 0 & 0 & 0 & 0.5 \\
\hline
\end{tabular}

*** $\mathrm{P}<0.0001$ : this difference is considered to be very highly statistically significant

Table ( 2 ) Micronuclei in polychromatic erythrocytes (PCEM) in bone marrow of rats treated with Aldicarb.

\begin{tabular}{||c|c|c|c|c|c||}
\hline \multirow{2}{*}{ Treatments } & \multirow{2}{*}{$\begin{array}{c}\text { Total No. Of } \\
\text { examined cells }\end{array}$} & \multicolumn{2}{|c|}{ PCEM } & \multirow{2}{*}{$\begin{array}{c}\text { Total No of } \\
\text { PCEM }\end{array}$} & Mean \pm SE \\
\cline { 5 - 6 } $\begin{array}{c}\text { G1 } \\
1 / 4 \text { LD50 of Aldicarb }\end{array}$ & 4000 & 201 & 71 & $272^{\star * *}$ & $68 \pm 1.825$. \\
\hline $\begin{array}{c}\text { G2 } \\
1 / 10 \text { LD50 of Aldicarb }\end{array}$ & 4000 & 188 & 36 & $224^{\star * *}$ & $56 \pm 2.15$. \\
\hline $\begin{array}{c}\text { G3 } \\
1 / 4 \text { LD50 of Aldicarb + Vitamin C }\end{array}$ & 4000 & 135 & 35 & $170^{\star * *}$ & $42 \pm 1.5$. \\
\hline $\begin{array}{c}\text { G4 } \\
1 / 10 \text { LD50 of Aldicarb + Vitamin C }\end{array}$ & 4000 & 92 & 24 & $116^{\star * *}$ & $29 \pm 1.29$. \\
\hline $\begin{array}{c}\text { G5 } \\
\text { Control of itamin C }\end{array}$ & 4000 & 22 & 8 & 30 & $7.5 \pm 0.645$ \\
\hline $\begin{array}{c}\text { G6 } \\
\text { Negative control }\end{array}$ & 4000 & 6 & 7 & 13 & $3.25 \pm 0.478$ \\
\hline
\end{tabular}

$* * * \mathrm{P}<0.0001:$ this difference consider to be very highly statistically significant. 
Fig (1) Metaphase plate of bone marrow cells showing types of chromosomal aberrations in rats treated with aldicarb
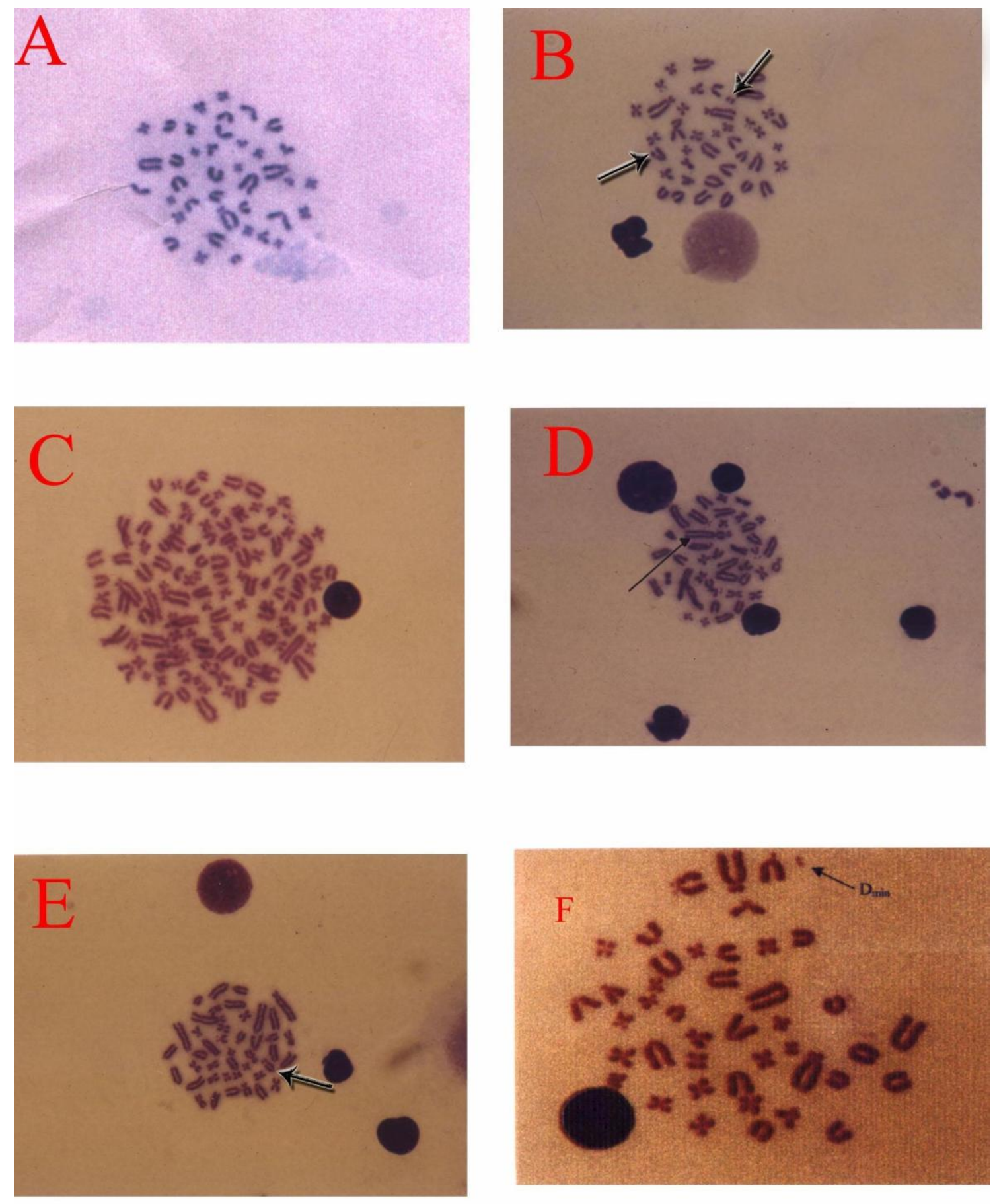
(A) Normal metaphase
(C) Polyploidy
(E) Break

(B) Acentric fragment\& gap

(D) Dicentri

(F) D-Minute 
Fig ( 2 ) photographs showing micronoclet in polychromatic erythrocytes (PCEM) in bone marrow of rats treated with Aldicarb
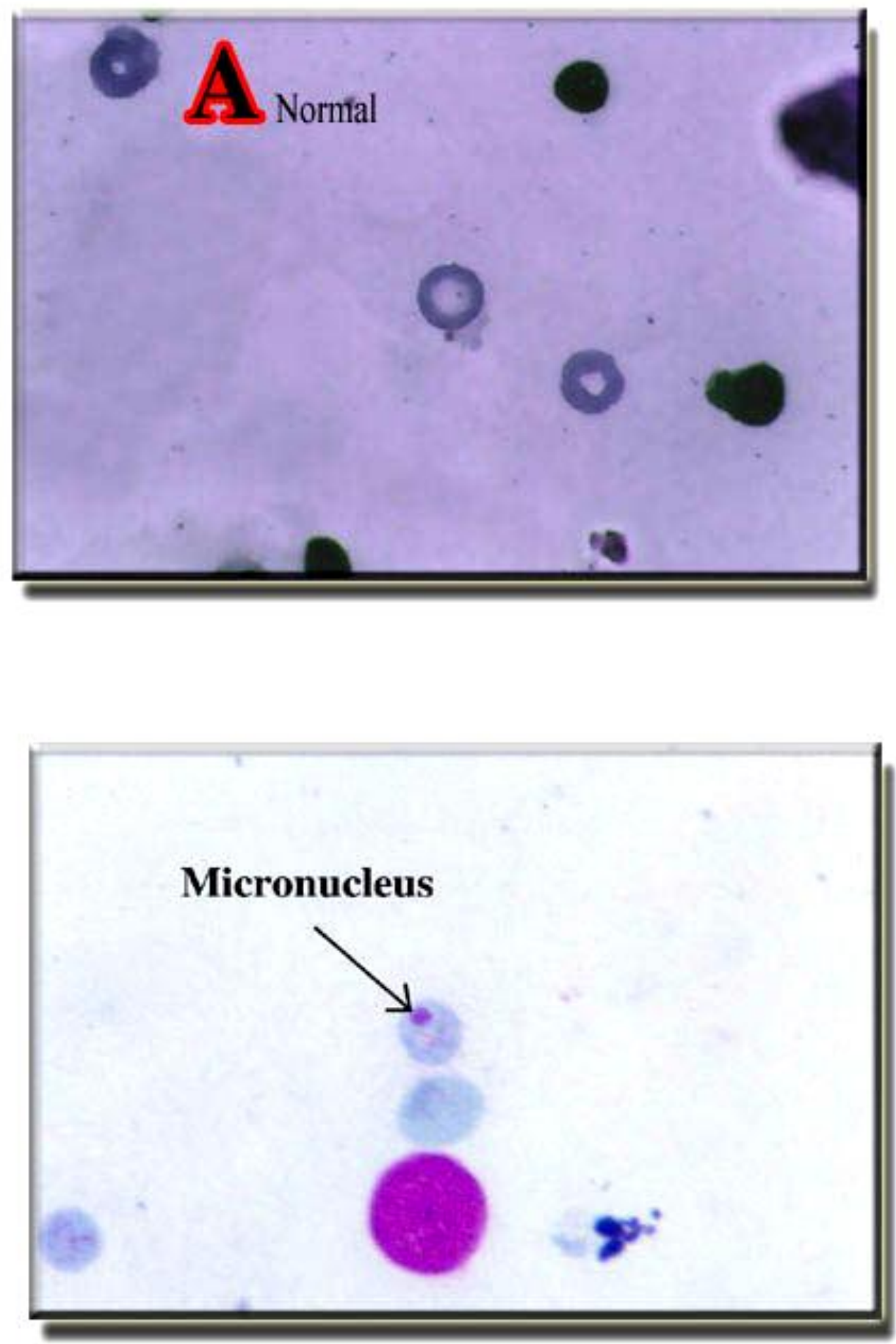


\section{Discussion}

The wide spread application of pesticides has produced cancer over their potential toxic and carcinogenic effects as well as toxic effect to a broad range of organisms either directly by exposure or indirectly by ingestion through the food chain (Vigfusion et al., 1983). On the other hand, Cravioto et al. (1977), found that the cytogenetic changes might depend also on interaction between several agents, or even between agents and hast factors e.g. DNA repair function, enzyme induction, and metabolism of pesticides, including insecticides, fungicides and herbicides. A limited number of field studies have also been done, aiming at obtaining epidemiological evidence for the presumptive genetic risk, at least at the somatic level for the human population.

Carbamates are a part of a large group of synthetic pesticides that have developed in the last 40 years. Carbamates are used in agriculture as insecticides, herbicides, fungicides and nematocides and due to their wide spread use, contamination of food, water, and air has become imminent and consequently adverse health effects are inevitable in humans, animals wildlife and fish (Essawy and Sobbhy, 1998).

There is a definite paucity of information on aldicarb mutagenic properties from direct experimental testing. There are only two reports on the mutagenicity of aldicarb from computer literature survey in 1979. The first deals with the mutagenic effect of aldicarb on petals and or/stamen hairs of mature flowers of various blue flowered Tradescantia clones (Sparrow and Schairer, 1974). The other deals with its effect on the DNA of normal human skin cultures, in which DNA was sedimented in alkaline sucrose gradients at various times after treatments (Blevin et al., 1977). Aldicarb was found to be non-mutagenic in both studies. Only one study Sharaf et al. (1982), was previously reported the effects of aldicarb on chromosomes of the laboratory animals using techniques comparable to our study.

In our study, we employed vitamin C as antioxidant agent in an attempt to decrease the potential risk of aldicarb. Vitamin C, which is natural antioxidant agents, may prevent the increase in free radicals produced by oxidative damage to lipids and lipoproteins in cellular components and tissues (Duthie et al., 1994; Sies et al., 1992). Thus, it may reduce certain types of the hepatic cellular degeneration (Harvey et al., 1994) .

In the present work, the genotoxic effect of aldicarb alone in the two used doses $(1 / 4$ and $1 / 10$ LD50) and in combination with vitamin $C$ was assessed in vivo using CA and $\mathrm{MN}$ assays. The aim of this investigation was to determine if there is an increase in genetic damage due to aldicarb treatment, and the possible protective role of vitamin $\mathrm{C}$ as antioxidant agent to minimize their mutagenicity.

The obtained data showed an increase in the induction of chromosomal aberrations in all treated groups of this experiment comparing with control group. This finding would indicate a clastogenic and or aneugenic effects related to the particular exposure to aldicarb. Although the induction of chromosomal aberrations in animals exposed to aldicarb and vitamin $\mathrm{C}$ is high compared to the negative control, otherwise when comparing with animals treated with aldicarb alone, the data showed a decrease in cytotoxicity of aldicarb due to the presence of vitamin $\mathrm{C}$.

In agreement with our study, Sharaf et al, (1982), administered aldicarb "temik" acutely by single intraperitoneal injection and sacrificing animals after 6,24 and $48 \mathrm{~h}$, and subacutely giving animals five daily injections with a single dose. This study showed an increase in CA in all experimental animals treated with aldicarb. Also, they found that, the significant chromosomal aberrations observed were both structural and numerical aberrations. The structural aberrations were in the form of gap, break, deletion, acentric fragment, dicentric, while the type of numerical aberration is polyploidy.

In the present work, the statistical analysis showed an increase in the induction of $\mathrm{CA}(\mathrm{P}<0.0001)$ in all treated 
animals from G1 to G6 comparing with negative control. The type of structural chromosomal aberrations was gap, followed with break, deletion, fragment, acentric fragment, minute and dicentric. Numerical aberrations as polypolidy cells were also observed. Nichols (1972), correlates chromosomal breaks to gene mutation in somatic cells. Also, Kato (1977) stated that the chromatid deletion may be due to incomplete sister chromatid exchanges, primarily fragment and deletion and this may be indication that chromosomal damage has occurred following the G1 stage of cell cycle. Our results indicated that the proportion of cells with structural aberrations was greater in animals groups treated with aldicarb with the percentage of $45.5 \%$ and $35 \%$ in G1and G2 respectively, while the percentage of aberrant cells decreased in the presence of vitamin $\mathrm{C}$ with the percentage of $32.5 \%$ and $25 \%$ in G3 and G4 respectively, this may be due to the protective role of vitamin $\mathrm{C}$ in reducing the genotoxicity of aldicarb. Regarding the numerical aberrations, it was found to be significantly increased in all treated groups with the percentage of $13.5 \%, 10 \%, 9 \%$ and $7 \%$ in G1, G2, G3 and G4 respectively. These findings suggest that aldicarb have a cumulative effect. The observed sturcural and numerical aberrations produced by aldicarb are suggestive of mutagenicity and carcinogenicity.

The micronucleus test has been used as an in vivo cytogenetic test to estimate the clastogenic potential; the finding that chemicals with clastogenic activities induce micronuclei, which may be due to chromatid or chromosome fragments or lagging chromosome induced by clastogenic or spindle poisons. In the present study aldicarb separately and in combination with vitamin $\mathrm{C}$ induce micronucleated cells, this may indirectly reflect chromosome breakage or impairment of the mitotic apparatus. The percentage of PCEM cells in was $6.8 \%, 5.6 \%, 4.2 \%, 2.9 \%, 0.75 \%$ and $0.325 \%$ in G1, G2, G3, G4, G5 and G6 respectively. The statistical analysis also revealed that there was highly significant increase in the induction of micronucleus (MN) in bone marrow cells treated with aldicarb only in G1 and G2 which decreased gradually from G3 and G4 till groups G5 and G6 (control groups).

Induction of micronuclei in the PCE of bone marrow cells has been regarded as one of the most sensitive bioassays for monitoring the mutagenic genotoxic effects of a compound (Heddle et al., 1983). Also, Hayashi et al. (1984), stated that the micronuclei induced by clastogenic chemicals in PCE of mouse bone marrow were directely derived from structural chromosomal aberrations, especially a centric fragment that appeared in preceding metaphase. In vitro study, Countryman and Heddle (1976), showed that dosimetric aspects of micronucleated cells agreed well with those expected from metaphase analysis of aberrations in cultured human lymphocytes irradiated by $x$-ray. In a vivo studies, on the other hand, the relation between chromosomal aberrations and micronuclei has been demonstrated only on the basis of theoretical consideration (Heddle and Carrano, 1977). Therefore, a detail analysis of micronucleus induction by spindle poisons is important to get a complete understanding of the mechanisms of micronucleus formation.

Thus in the present study, an increased frequency of micronucleated cells is a biomarker of genotoxic effect that can reflect exposure to agents with clastogenic (chromosome breaking, DNA as target) or aneugenic (aneuploidogenic., effect on chromosome number., mostly non -DNA target) modes of action (Titenko-Holland et al., 1997). This in agreement with Sharaf et al (1982), who found that a significant increase in the micronucleus frequency and structural chromosomal aberrations in aldicarb treated animals after 6, 24 and $48 \mathrm{~h}$ of injection. Also, Wei et al. (1997), studied three carbamate insecticides (propoxur, methyomyl and aldicarb) for their ability to induce micronuclei (MN) in vitro using marrow erythrocytes. They found that these tested insecticides induced a significant increase in micronucleated cells and structural and/ or numerical chromosomal aberrations in mammalian cells.

In fact a variety of pesticides are present in the environment and it is possible that the combination of several toxic molecules at sub-threshold doses might 
have genotoxic effects not predictable by simple additive models. It is generally accepted that chromosomal abnormalities are causal events in the development of neoplasia, and it has earlier been postulated, but not proven, that increased chromosomal damage may reflect an enhanced cancer risk. So, the importance of such genotoxic effects is the initiation of cancer. Hagmar $e t$ al. (1994), stated that an increased level of chromosomal breakage appeared to be a relevant biomarker of future cancer risk. In addition, double minute are rare among normal cells, but both aberrations are found in tumor cells. Recently performed epidemiological studies of Bonassi et al. (2000), showed that the chromosomal aberrations frequency predicts the overall cancer risk in healthy subjects.

\section{Conclusion}

The present study proved that the tested pesticide "aldicarb" induced a significant increase in abnormal cells (containing structural chro-matid type and chromosome type aberrations, and numerical aberration "polyploidy") as well as the total number of aberrations, and micronucleated polychromatic erythrocytes. The presence of vitamin $\mathrm{C}$ in combination with aldicarb decreased the cytotoxic effect of aldicarb, therefore vitamin $\mathrm{C}$ decreased the genetic damage of aldicarb.

These data supported the view of many authors who have indicated the high sensitivity of the end points $\mathrm{CA}$ and $\mathrm{MN}$ that employed in the genotoxicity testing. The obtained results are also warrant future studies to evaluate the heritable genetic changes as well as carcinogenicity.

\section{References}

1. Alder, I.D. (1984) : Cytogenetic tests in mammals. Cited in: venilt.S. and Parry, S.M., Mutagenicity Testing. A practical Approach. I.R.L. press, Oxford, Washington, D.C. 275-306.

2. Baron, R.L.(1994) : A carbamate insecticide: A case study of aldicarb. Environ Health Perspect 102 (supp 11) : 23-37.

3. Blevin, R.D., Lijinsky,W and Regan,J.D. (1977) : Nitrosated methyle carbamate insecticides: effects on the DNA of human cells. Mutat. Res. $44: 1$.

4. Bonassi, S., Hagmar, L., Stromber, G.V., Huici-Montagued, A., Tinnerberg, H., Forni, A., Heikkila, P., Wanders, S., Wilhardt, P., Hansteen, I.L., Knudsen, L.E. and Norrpa, H., : The European study group i.e. and Health (ESCH) (2000) : Chromosomal aberrations in lymphocytes predict human cancer. Independently from exposure to carcinogensis. Cancer. Res. 60 : 1619-1625.

5. Carrano, A.V and Natarajan, A.T. (1988): Considerant ions for population monitoring using cytogenetic techniques. Mutat. Res. 204: 379 - 406.

6. Countryman, P.I. and Heddle, J.A. (1976) : The production of micronuclei from chromosome aberrations in irradiated cultures of human lymphocytes. Mutat. Res. $41:$ 318-319.

7. Cravioto, F.F, Gayon, C.Z., Kolmodin, B., Lombert, B, Lindsten, J., Norberg, E., Nordenskjold, M., Olin,R. and swensson, A.(1977): chromosome aberrations and sister chromatid exchanges workers in chemical laboratoier and a rotoprinting factory and in children of women laboratory workers. Lancet.13: 322-325.

8. da-Silva, L.C., Liebes, S.R., Ruiz, M.A. and de-Souza, C.A. (1997) : Micronucleus monitoring to assess human occupational exposure to organochloride. Environ. Mol. Mutagen. 29 : 46-52.

9. Duthie, G.G., Wahle, W.J. and James, W.T. (1994): Oxidant, antioxidant and cardiovascular diseases. Nutr Res Rev 2:5162.

10. El-Khatib, E.N. and Rokaya, H.S.(2001): Genotoxic effects of two pesticides and their mixture : In -Vivo chromosomal aberrations and micronucleus assay.J.Union Arab. Biol Vol. (16A): Zoology: 355-380, Nov.

11. Essawy, G.S. and Sobbhy, H.M. (1998) : Effect of Marshal (carbosulfan, methyl carbamate) on reproductive system and thyroid gland of male rats. Vet. Med. J. Giza. Vol 46, No. 4B, 809-819.

12. Evans, H.J.(1977): Molecular mechanisms in the induction of chromosome aberratoins, in: D.Scott, B.A.Bridges, F.H.Sobels (Eds),,Progeren in Genetic Toxicology, Elsevier North Holland Biomedical Press,P.P 57-74.

13. Fenech, M. (1993): The Cytogenetic black micronucleus technique: A detailed description of the method and its 
application to genotoxicity studies in human population. Mutat. Res. 282: 35-44.

14. Goldman, L.R. (1995) : Case studies of environmental risks to children. Future. Child 5, 27-33.

15. Goldman, L.R., Beller, M. and Jackson, R.J. (1990): Aldicarb food poisonings ib California, 1985-1988 toxicity estimates for humans. A rchives of Environmental Health. 45 :3, 141-147.

16. Gomez-Arroyo, S.; Diaz-Sanchez, Y.; Menesus Perez, M.A. ; VillalobosPietrini, R. and De-Leon-Rodriguez, J. (2000): Cytgenetic biomonitaring in a Mexican floriculture Workers group exposed to pesticids. Mutat. Res. 466:117124

17. Hagmar, L. ; Bragger A- and Hanrteen . (1994): Cancer risk predicted by increased levels of Chromromal aberations in human lymphocytes: Nordic study group on the health risk of chromosome damage. Cancer Res. 54: 2919-2922.

18. Harvey, R.B., Kubena, L.F. and Elissalde, M. (1994): Influence of vitamin $\mathrm{E}$ on alfatoxicosis in growing swine. Am J Vet Res 55 : 572-577.

19. Hayashi, M.; Sofuni, T. and Ishidate, j. (1984): Kinetics of micronucleus formation in relation to chromosomal aberration in mouse bone marrow. Mutat. Res. 127:129-137

20. Heddle, H.J.(1973): A rapid in vivo test for chromosome damage. Mutat. Res. 18: 187-192

21. Heddle, J.A. and Carrano, A.V. (1977) : The DNA content of micronuclei induced in mouse bone marrow by y-iradiation: Evidence that micronuclei arise from acentric chromosomal fragments. Mutat. Res. 44 : 63-69.

22. Heddle, J.A., Hite, M., Kirkhart, B., Mavourin, K., Mac Gregor, J.T., Newel, W. and Salamone, M.F. (1983) : The induction of micronuclei as a measure of genotoxicity. A report of the U.S. Environmental Production Agency Gene. Toxicology Program. Mutat. Res. 123 : 61.

23. IARC. (1991): Monograph on the evaluation of carcinogenic risks to humans, occupational exposure in insecticide application, and some pesticides, International Agency for Research on Cancer, Lyon. Vol, 53.

24. Kato, H. (1977) : Mechanisms for sister chromatid exchanges and their relation to the production of chromosomal aberrations. Chromosoma (Berl.) 59 : 179-191.
25. Kirsch-Volders, M., Elhajouji, A., Cundari, E. and Van. Hummelen, P. (1997) : The in vitro micronucleus test. A multi-end-point assay to detect simultameously mitotic delay, apoptosis, chromosome, Mutat. Res. 392 : 19-30.

26. Natarajan, A.T. and Obe, G. (1982): Mutagenicity testing with cultured mammalian cells: cytogenetic assays, in: J.A. Heddle (E.d.), Mutagenicity: New Horizons in Genetic Toxicology, Academic Press, New York, pp. 171-213.

27. Netke, S.P., Roomi, M.V. and Tsao, C (1997) : Ascorbic acid protects guinea pigs from acute alfatoxin toxicity. Toxicol Appl Pharmacol, 143: 429-435.

28. Nichols, W. (1972): Genetic hazards of drugs of abuse. In Zenafonctics. C.F.D. (ed)"Drug Abuse" proceedings of international conference, Lea and Febiges.

29. Pastor, S., Gutierrez, S., Creus, A., Cebulska,-Wasilewska, A. and Marcos, R. (2001): Micronuclei in peripheral blood lymphocytes and buccal epithelial cells of polish farmers exposed to pesticides. Mutat. Res. 495: 147-156.

30. Preston, R.J., Deen, B.J., Galloway, S., Holden, H., Mc fee, A.F. and Shelby, M. (1987) : Mammalian in vivo-cytogenetic assays : Analysis of chromosome aberrations in bone marrow cells. Mutat. Res. 21 : 187-188.

31. Przygoda, R.T., Mc-Kee, R.H., Amoruso, M.A. and Freeman, J.J. (1999): Assessment of the utilitz of the micronucleus test for petroleum- derived materials. Mutat. Res. 438 :145-153.

32. Risher, J.F., Mink, F.L. and Stara, J.F. (1987): The toxicologic effects of the carbamate insecticides aldicarb in mammals : A review. Environ. Health Perspect. 72 :267-281.

33. Schmid, W.(1975): The micronucleus test. Mutat. Res. 21: 187-188.

34. Sendecore, G. (1969): "Statistical method" Aiwa state Univ. press.Ames., USA. Fourth Edition.

35. Sharaf, A.A., Temtamy, S.A, De-Hondt, H.A., Belal, M.H. and Kassam, E.A. (1982): Effect of aldicarb (temik) a carbamate insecticide on chromosomes of the laboratory rat. Egypt. J. Genet. Cytol., 11 (2), 143-152.

36. Sies, H., Stahl, W., Sundquist, A.R. (1992): Antioxidant function of vitamin: Vitamins C\&E, B-carotene and other carotenoids. Ann New York Acad Sci 669: 7-12. 


\section{Fatma M. Hamam \& Ihab H. Foda}

37. Sparrow, A.H. and L.A. Schairer (1974) : Mutagenic response of trade-cantia to treatment with $\mathrm{x}$-ray, EMS-DBE, ozone, So2, No2 and several insecticides. Mutat. Res. $26: 445$.

38. Surralles, J., Carbonell, ae., Marcos, R., Degrassi, F., Antoccia, A. and Tanzarella, A.(1992): A collaborative study on the improvement of the micronucleus test in cultured human lymphocytes. Mutagensis 7(6): 407-410.

39. Titenko-Holland, N., Windhom, G., Kolachana, J., Rinisch, F., Parvatham, S., Asorio, A.M. and Smith, M.T.(1997): Genotoxcity of malathion in human lymphocytes assessed using the micronucleus assay in vitro and in vivo: a study of malathion exposed workers. Mutat. Res. 338: 85-95.

40. Vigfusion, N.V., Vyse, E.R. Persteiner, C.A. and Dawson, R.J. (1983): In vivo induction of sister chromatid exchange in Umbra Limi by the insecticides endrin, chlordane, diazinon and guthion. Mutat. Res. 118: 61-68.

41. Wei, L.Y., Chao, J.S. and Hong, c.c. (1997): Assessment of the ability of prpoxur, methomyl, and aldicarb, three carbamate insecticides, to induce micronuclei in vivo in $\mathrm{BALB} / \mathrm{C}$ mice. Environmental and Molecular Mutagenesis, 29: 4, 386-393. 
دراسات طفرية على تأثثير مبيد الايكارب (تيمك) وفيتامين c كعامل

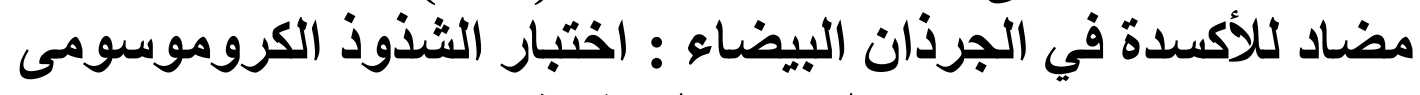

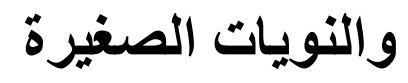

$$
\text { فاطمة محمد همام ، أبهاب حسنى فوده }
$$

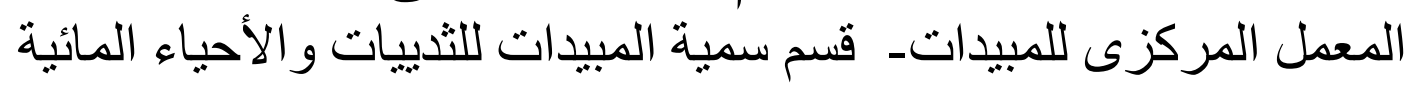

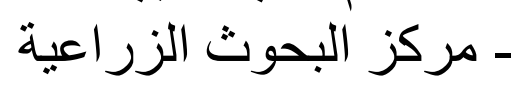

الانتشار الواسع لتلوث البيئة يرجع إلى الزيادة المستمرة في الاستخدام

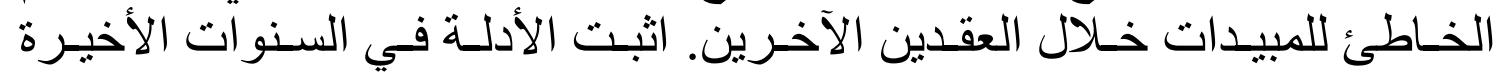

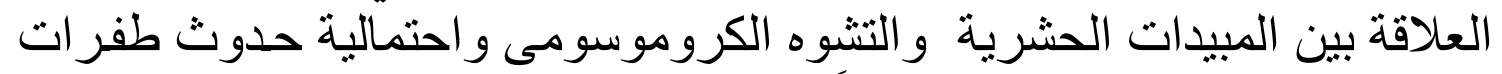

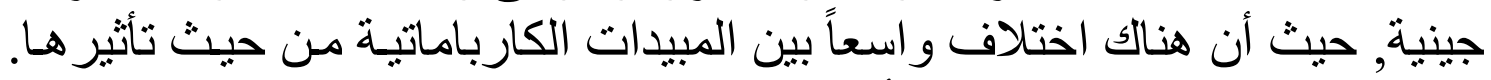

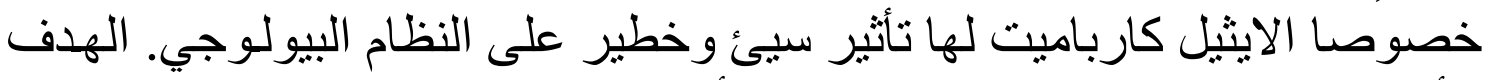

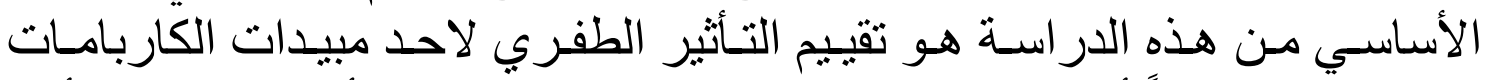

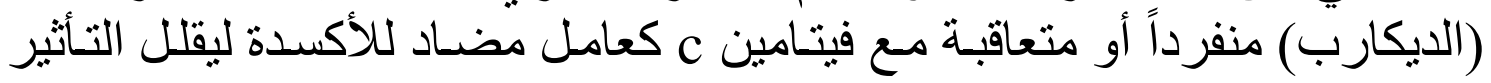

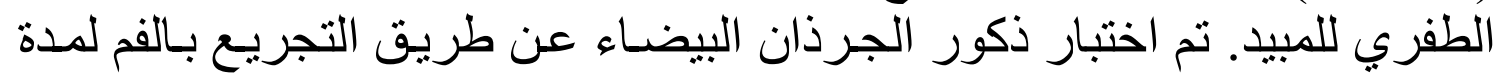

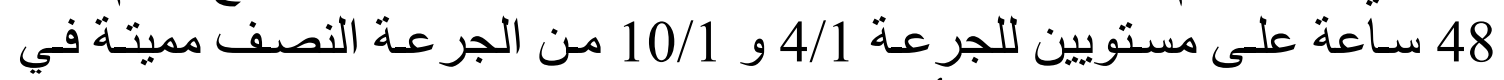

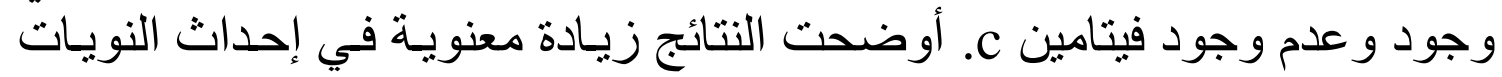

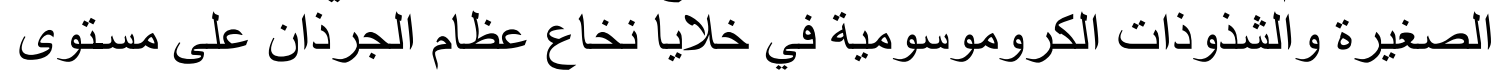

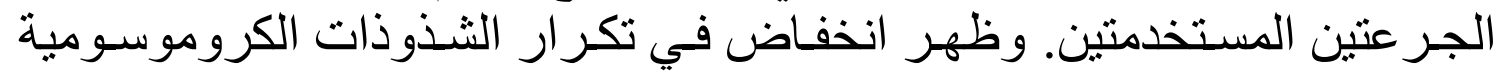

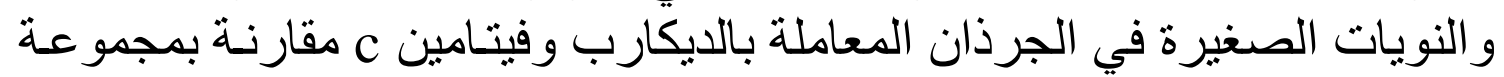

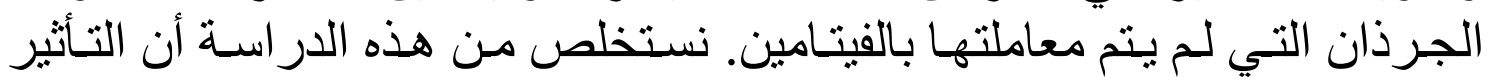
الطفري لمبيد الديكارب ربما ينخفض مع استخدام فيتامين c. 